\title{
Edugame Operasi Hitung Matematika untuk Anak Sekolah Dasar (SD) Berbasis Android
}

\author{
Devi Afriyantari Puspa Putri \\ Fakultas Komunikasi dan Informatika, \\ Universitas Muhammadiyah Surakarta \\ dap129@ums.ac.id
}

\begin{abstract}
Proses pembelajaran merupakan hal yang penting bagi kehidupan manusia, jenjang pembelajaran di Indonesia dibagi menjadi tiga tingkatan. Salah satu pelajaran yang dipelajari di semua tingkatan adalah matematika. Matematika merupakan pelajaran yang cukup penting karena dapat membantu siswa dalam menyelesaikan masalah, namun sebagian siswa merasa kesulitan untuk mempelajarinya. Hal ini dikarenakan sistem pembelajaran yang konvensional, dengan berkembanganya teknologi maka proses pembelajaran dapat diubah kearah yang lebih menarik. Tujuan dari penulis adalah membuat aplikasi edugame untuk operasi hitung berbasis android yang dapat membantu proses pembelajaran. Software buildbox dan android studio dipakai untuk membuat aplikasi ini. Dari hasil uji buildbox menyatakan bahwa aplikasi berjalan dengan baik, serta kuesioner menunjukkan bahwa aplikasi ini dapat membantu proses pembelajaran menjadi lebih menarik.
\end{abstract}

Keywords: edugame, buildbox, android, operasi hitung

\section{PENDAHULUAN}

Proses pembelajaran merupakan hal yang penting bagi seluruh manusia, karena dengan melaui proses tersebut manusia bisa baeradapatasi dan memanfaatkan lingkungan sekitar. Jenjang pembelajaran wajib belajar di Indonesia dibagi menjadi tiga tingkatan yaitu Sekolah Dasar (SD), Sekolah Menengah Pertama (SMP), dan Sekolah Menengah Atas (SMA). Matematika merupakan salah satu pelajaran yang dipelajari di semua jenjang pendidikan.

Hal ini dikarenakan matematika mempunyai manfaat yang cukup penting dalam proses penyelesaian masalah serta melatih otak untuk berpikir secara struktur dan sistematis [1]. Selain itu, menurut [2] matematika sangat bermanfaat karena dapat digunakan untuk proses berkomunikasi dalam kehidupan sehari-hari, memberikan ketelitian serta berpikir secara logis mengenai suatu masalah dan juga dapat melatih manusia dalam memecahkan suatu masalah yang muncul. Berdasarkan kegunaan yang sudah dijabarkan dapat disimpulkan bahwa pembelajaran matematika sangat penting untuk semua jenjang khususnya pada SD yang merupakan tingkat dasar penanaman pelajaran, namun terdapat beberapa hambatan yang muncul dalam proses pembelajarannya.

Saat ini mata pelajaran matematika menjadi salah satu yang cukup sulit untuk diserap oleh siswa karena beberapa faktor, seperti proses pengajaran yang terlalu teoritis, proses belajar mengajar yang masih menggunakan metode konvensional. Selain itu, matematika menjadi sangat sulit karena siswa merasa topik yang disampaikan terlalu serius sehingga dapat menghambat murid untuk menyerap pelajaran [3].

Salah satu metode yang bisa digunakan untuk mengatasi masalah yang timbul adalah dengan membawa suasana yang santai dalam proses pembelajaran seperti belajar sambil bermain dalam proses pengajarannya, membuat game edukasi merupakan salah satu solusi yang bisa digunakan. Menciptakan suasana yang menyenangkan dalam proses pembelajaran dapat meningkatkan keefektifan dan daya serap siswa dalam menerima pelajaran matematika [3].

Dengan berkembangnya teknologi saat ini memberikan dampak positif bagi kehidupan dan juga merubah gaya hidup manusia termasuk pendidikan. Salah satunya, yaitu meningkatnya penggunaan teknologi mobile khususnya smartphone berbasis android, yang dapat memudahkan pekerjaan manusia. Saat ini cukup banyak metode yang menggabungkan teknologi mobile dan pendidikan seperti pembuatan media pembelajaran seperti game edukasi (edugame). Edugame merupakan konsep yang menggabungkan edukasi atau hiburan dengan game. Tujuan dari suatu edugame adalah untuk mengajak pemain selain mendapatkan hiburan juga bisa menambah pengetahun serta belajar tanpa disadari[4]. Edugame bisa dikategorikan masuk kedalam tipe serious game karena tujuan utama dalam memainkannya bukanlah untuk entertainment [5]. 
Dengan adanya sentuhan teknologi seperti multimedia didalam proses pengajaran dapat meningkatkan inovasi serta kreativitas yang dapat mendorong motivasi belajar dan proses penyerapan materi bagi siswa. Berdasarkan pendapat dari [6], mengungkapkan bahwa keterlibatan multimedia dalam proses pengajaran dapat mengubah metode pembelajaran konvensional menjadi pembelajaran yang aktif dan menuntut siswa untuk turut berpartisipasi. Berdasarkan pemaparan yang ada, maka penulis membuat suatu aplikasi yaitu "Edugame Operasi Hitung Matematika untuk Anak Sekolah Dasar (SD) Berbasis Android. Aplikasi ini bertujuan untuk membantu penyelesaian masalah yang ada dalam proses pembelajaran khususnya dalam membawa suasana yang menyenangkan di dalam kelas, serta mengubah proses pengajaran konvensional menjadi pengajaran yang lebih aktif.

\section{TINJAUAN PUSTAKA}

Beberapa penelitian mengenai edugame pada anak sekolah sudah dilakukan, seperti [7] yang menggunakan metode Linear Congruent Method (LCM) untuk pembelajaran baca tulis hitung (calistung) untuk anak usia 3-8 yang berbentuk aplikasi berbasis android. Hasil dari penelitiannya mengemukakan bahwa aplikasi android calistung menggunakan metode LCM dapat meningkatkan minat belajar anak-anak usia dini. Penelitian lain [8] membahas tentang pembuatan aplikasi game puzzle dengan tiga materi matematika yaitu teori bilangan, geometri serta materi aljabar. Pembuatan game ini menggunakan aplikasi appgeyzer, dari hasil penggunaan tiga ptoyotype dalam tahapan percobaan didapatkan kesimpulan bahwa aplikasi game puzzle untuk pembelajaran matematika pada anak SD sangat menarik.

Pada penelitiannya [9] mengungkapkan bahwa dalam proses perancangan edugame menggunakan software construct 2 dan metode bantu yang digunakan adalah Unified Modeling Languange ( $U M L$ ) untuk proses menganalisa aplikasinya. Untuk aplikasi edugame matematik pada penelitian ini terdiri dari empat level permainan yaitu proses penjumlahan, pengurangan, perkalian, dan pembagian.

Berdasarkan dari penelitian-penelitian serupa sebelumnya, dapat disimpulkan bahwa pengaplikasian edugame dalam proses pembelajaran matematika dapat meningkatkan minat siswa dalam belajar. Oleh karena itu, penulis membuat aplikasi edugame mengenai operasi hitung matematika berbasis android menggunakan buildbox dan untuk tahapan analisa nya akan menggunakan UML untuk membantu proses analisa.

\section{METODE PENELITIAN}

Metode penelitian dalam aplikasi ini menggunakan metode software development life cycle ( SDLC) Waterfall, dikarenakan persyaratan analisis yang dibutuhkan sudah ditentukan diawal dan proses pengerjaannya harus dikerjakan secara berurutan dan tahapan testing akan dilakukan hanya di akhir proses, serta dengan menggunakan metode waterfall akan meminimalisir sumber daya yang digunakan [10]. Metode yang akan digunakan pada penelitian ini bisa dilihat pada gambar 1 .

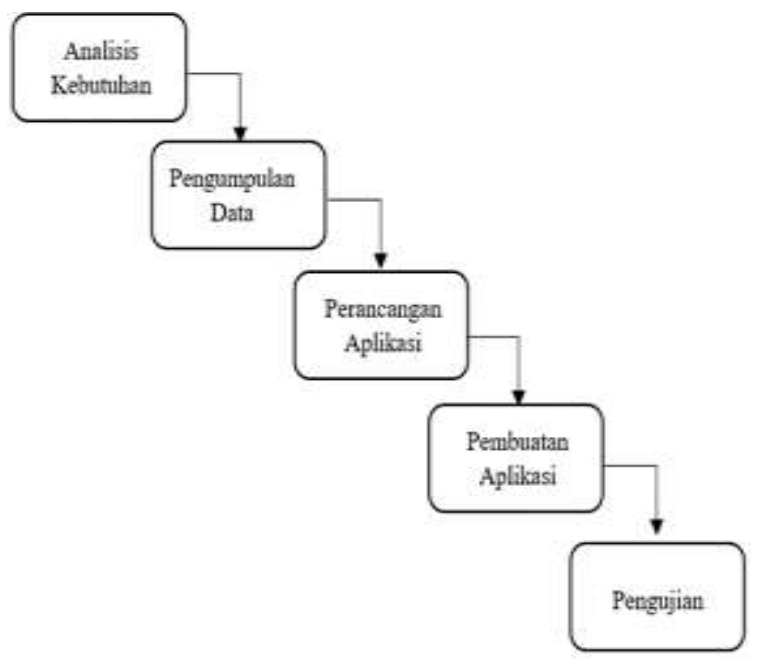

Gambar 1. Metode Penelitian Waterfall

Dalam gambar 1, terlihat lima tahapan yang diperlukan untuk membuat sebuah aplikasi edugame matematika ini, setiap tahapan akan dijelaskan pada bagian subbab berikut.

\section{Analisa Kebutuhan}

Dalam tahapan ini, penulis melakukan analisa terhadap kebutuhan materi dengan melihat ke kurikulum yang digunakan untuk anak SD, dan juga melihat buku teks yang digunakan untuk mengatur tingkat kesulitan, serta merujuk kepada teknik pengembangan aplikasi berbasis android agar sesuai dengan yang dibutuhkan.

Pengumpulan Data

Pengumpulan data dilakukan dengan melakukan pengamatan terhadapt buku teks siswa SD dan mengelompokkan soal-soal operasi matematika menjadi empat bagian penjumlahan, pengurangan, perkalian serta pembagian, untuk tingkat kesulitan soalnya diatur secara bertahap.

\section{Perancangan Aplikasi}

Perancangan aplikasi dibagi menjadi dua bagian yaitu storyline yang berisi tentang alur pengoperasian aplikasi edugame dan storyboard yang merupakan gambaran dari aplikasi dari munculnya halaman utama sampai pengguna menutup aplikasi. Use case diagram yang digunakan untuk memperlihatkan alur dari aplikasi ini sehingga dapat dilakukan evaluasi terhadap aplikasi apabila terjadi ketidaksesuaian sebelum kode program dituliskan [11]. Use case diagram dapat dilihat pada gambar 2 . 


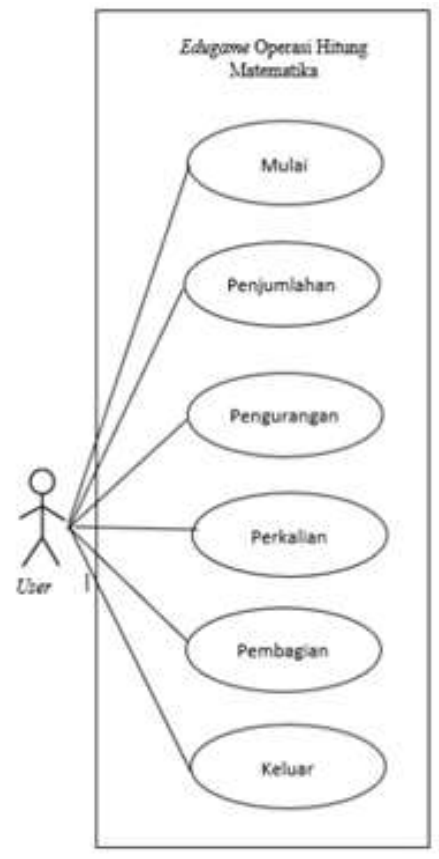

Gambar 2. Use case diagram

Pembuatan Aplikasi

Proses pembuatan aplikasi dilakukan dengan mengimplementasi hasil dari perancangan yang sudah dibuat sebelumnya. Pembuatan aplikasi edugame matematika melibatkan software, hardware serta asset yang dapat dilihat pada tabel 1 .

Tabel 1. Tools Pembuatan Aplikasi

\begin{tabular}{|l|l|l|}
\hline Software & Hardware & Asset \\
\hline Buildbox & $\begin{array}{l}\text { Smart Phone } \\
\text { Samsung Galaxy } \\
\text { S4 }\end{array}$ & $\begin{array}{l}\text { Semua } \text { asset } \\
\text { diambil dari } \\
\text { freepik.com }\end{array}$ \\
\hline $\begin{array}{l}\text { Coreldraw } \\
2018\end{array}$ & $\begin{array}{l}\text { Laptop Asus } \\
\text { UX303 UB }\end{array}$ & \\
\hline Windows 10 & & \\
\hline Android Studio & & \\
\hline SDK & & \\
\hline JDK & & \\
\hline
\end{tabular}

\section{Pengujian}

Tahapan pengujian merupakan tahapan terakhir dari proses pembuatan aplikasi, pengujian menggunakan blackbox dan kuesioner yang merujuk pada User Acceptance Testing (UAT). Pengujian menggunakan blackbox sangat tepat digunakan karena hanya fungsionalitas dari sistem yang akan diuji, serta pengguna yang menguji aplikasi ini tidak memiliki pengetahuan terhadap proses pemgroraman yang digunakan pada aplikasi ini [12]. Kuesioner berbasis UAT digunakan agar dapat memastikan semua fungsi yang ada didalam aplikasi ini sudah memenuhi kelayakan dan kriteria yang ditetapkan oleh pengguna aplikasi [13]. Skala yang digunakan pada kuesioner merujuk pada skala likert [14] yang menggunakan lima skala, dibagi menjadi : sangat setuju (SS), setuju (S), netral (N), tidak setuju (TS), sangat tidak setuju (STS). Proses pengujian aplikasi ini dilakukan di SD Negeri 1 Getasrejo, Grobogan yang dilakukan oleh 30 siswa, karena menurut [15] penelitian dikatakan memenuhi standar sample, apabila sample diambil oleh rentang koresponden antara 30 hingga 500 orang. Proses penghitungan presentase dari kuesioner menggunakan rumus :

$$
\text { Presentase }=\frac{\text { total nilai }}{\text { skor ideal }} \times 100 \%
$$

\section{HASIL PENELITIAN DAN PEMBAHASAN}

Penelitian ini, menghasilkan aplikasi edugame matematika yang proses perancangannya sudah dijelaskan pada bab III. Terdapat beberapa tampilan gambar yang diambil dari aplikasi edugame, yang akan dibahas pada bab ini.

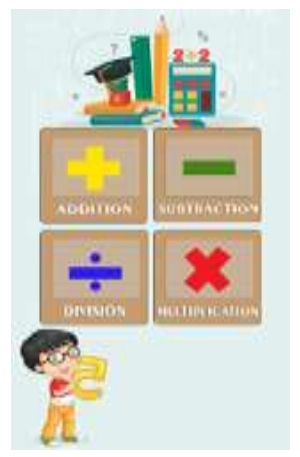

Gambar 3. Tampilan halaman awal dari edugame operasi hitung

Pada gambar 3, terdapat pilihan menu dari empat operasi hitung yang ada yaitu penjumlahan, pengurangan, pembagian, dan perkalian. Keempat menu yang ada akan menampilkan soal yang sesuai dengan operasi hitung yang dipilih.

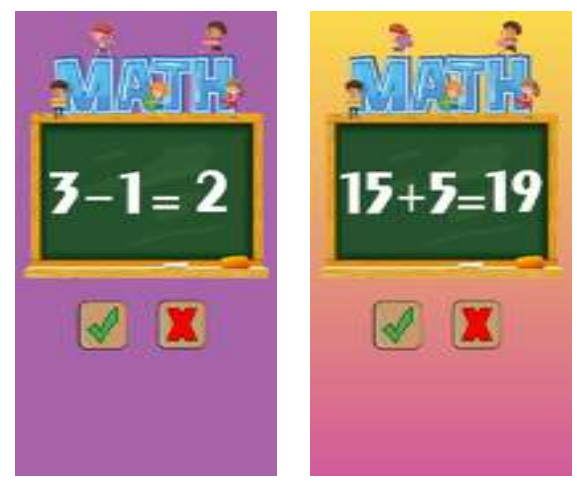

Gambar 4. Contoh tampilan soal operasi hitung

Gambar 4 menampilkan contoh tampilan operasi hitung, pada halaman ini terdapat dua pilihan benar dan salah terhadap pernyataan dari operasi hitung yang ditampilkan. Saat pengguna memilih jawaban yang tepat, maka akan muncul soal operasi hitung lainnya. Sebaliknya apabila jawaban yang dipilih tidak sesuai maka akan beralih ke halaman coba lagi. 


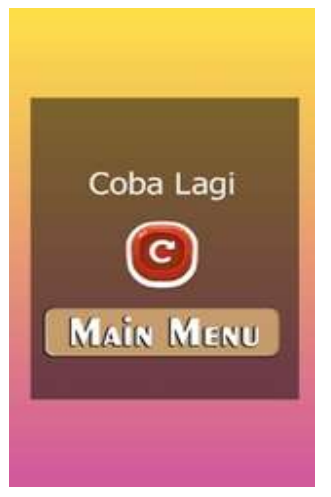

Gambar 5. Halaman Coba Lagi

Gambar 5 adalah halaman coba lagi, yang akan muncul apabila jawaban dari pengguna kurang tepat. Halaman ini memiliki dua pilihan yaitu bermain lagi untuk jenis soal operasi hitung yang sama, atau kembali ke halaman menu utama.

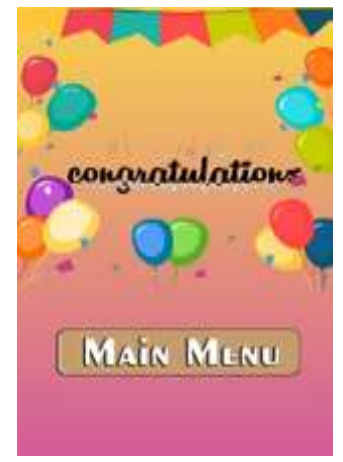

Gambar 6. Halaman Sukses

Gambar 6 merupakan tampilan yang akan muncul, apabila pengguna sudah selesai menjawab semua soal dengan tepat. Pada aplikasi ini terdiri dari 20 soal untuk setiap operasi penghitungan.

Pembahasan menampilkan hasil dari pengujian menggunakan blackbox, serta hasil kuesioner yann berdasarkan dari proses pengujian aplikasi yang telah dibahas di bab III. Hasil pengujian blackbox terhadap aplikasi dapat dilihat pada tabel 2 .

Tabel 2. Hasil Pengujian Blackbox

\begin{tabular}{|c|c|c|c|}
\hline Halaman & Tombol pada & \multicolumn{2}{|c|}{ Hasil Evaluasi } \\
\cline { 3 - 4 } & Aplikasi & Valid & $\begin{array}{c}\text { Tidak } \\
\text { Valid }\end{array}$ \\
\hline $\begin{array}{c}\text { Menu } \\
\text { Utama }\end{array}$ & Penjumlahan & $\mathrm{V}$ & \\
\hline & Pengurangan & $\mathrm{V}$ & \\
\hline & Pembagian & $\mathrm{V}$ & \\
\hline $\begin{array}{c}\text { Soal Operasi } \\
\text { Hitung }\end{array}$ & Perkalian & $\mathrm{V}$ & \\
\hline & Benar & $\mathrm{V}$ & \\
\hline Coba Lagi & Salah & $\mathrm{V}$ & \\
\hline & Main Mentart & $\mathrm{V}$ & \\
\hline Sukses & Main Menu & $\mathrm{V}$ & \\
\hline
\end{tabular}

Hasil dari tabel 2 membuktikan bahwa semua tombol dan fungsionalitas dari aplikasi edugame operasi matematika ini berjalan dengan baik tanpa adanya kesalahan fungsi yang muncul. Selanjutnya, hasil dari kuesioner yang diisi oleh 30 responden mengenai aplikasi ini, dapat dilihat pada tabel 3.

Tabel 3. Hasil Kuesioner pada Aplikasi

\begin{tabular}{|c|c|c|c|c|c|c|c|}
\hline \multirow[t]{2}{*}{ No } & \multirow[t]{2}{*}{ Pertanyaan } & \multicolumn{5}{|c|}{ Pilihan Jawaban } & \multirow{2}{*}{$\begin{array}{l}\text { Prese } \\
\text { ntase }\end{array}$} \\
\hline & & SS & $\mathrm{S}$ & $\mathrm{N}$ & TS & STS & \\
\hline 1 & $\begin{array}{l}\text { Aplikasi } \\
\text { edugame ini } \\
\text { sangat } \\
\text { menarik dan } \\
\text { menantang }\end{array}$ & 2 & 23 & 5 & & & $78 \%$ \\
\hline 2 & $\begin{array}{l}\text { Aplikasi ini } \\
\text { mudah untuk } \\
\text { dimainkan }\end{array}$ & 5 & 21 & 4 & & & $\begin{array}{r}80,67 \\
\% \\
\end{array}$ \\
\hline 3 & $\begin{array}{l}\text { Aplikasi ini } \\
\text { dapat } \\
\text { membantu } \\
\text { dalam proses } \\
\text { pembelajaran } \\
\text { matematika }\end{array}$ & 8 & 16 & 6 & & & $\begin{array}{r}81,33 \\
\% \\
\end{array}$ \\
\hline 4 & $\begin{array}{l}\text { Tampilan } \\
\text { pada aplikasi } \\
\text { ini menarik }\end{array}$ & 7 & 19 & 3 & 1 & & $\begin{array}{r}81,33 \\
\% \\
\end{array}$ \\
\hline 5 & \begin{tabular}{l}
\multicolumn{2}{l}{ Tombol- } \\
tombol pada \\
aplikasi ini \\
mudah \\
digunakan
\end{tabular} & 10 & 18 & 2 & & & $\begin{array}{r}88,67 \\
\%\end{array}$ \\
\hline 6 & $\begin{array}{l}\text { Bahasa yang } \\
\text { digunakan } \\
\text { pada aplikasi } \\
\text { ini jelas }\end{array}$ & 12 & 15 & 3 & & & $\begin{array}{r}86,00 \\
\%\end{array}$ \\
\hline 7 & $\begin{array}{l}\text { Halaman- } \\
\text { halaman pada } \\
\text { aplikasi dapat } \\
\text { dioperasikan }\end{array}$ & 5 & 21 & 4 & & & $\begin{array}{r}80,67 \\
\% \\
\end{array}$ \\
\hline 8 & $\begin{array}{lr}\text { Materi } & \text { kuis } \\
\text { pada aplikasi } \\
\text { ini } & \text { sudah } \\
\text { sesuai } & \end{array}$ & 10 & 18 & 2 & & & $\begin{array}{r}85,33 \\
\%\end{array}$ \\
\hline 9 & $\begin{array}{l}\text { Aplikasi ini } \\
\text { dapat } \\
\text { meningkatkan } \\
\text { minat belajar }\end{array}$ & 5 & 21 & 4 & & & $\begin{array}{r}80,67 \\
\%\end{array}$ \\
\hline & rata total preser & & & & & & $\begin{array}{r}82,52 \\
\%\end{array}$ \\
\hline
\end{tabular}

Berdasarkan dari rata-rata total presentase sebesar $82,52 \%$ menyatakan bahwa aplikasi edugame operasi hitung untuk anak kelas SD berbasis android sangat baik dan berjalan sesuai dengan apa yang diharapkan.

\section{KESIMPULAN}

Berdasarkan hasil pengujian yang ada pada bab IV, dapat disimpulkan bahwa aplikasi edugame operasi hitung matematika ini dapat digunakan, serta dapat membantu murid SD untuk belajar matematika khususnya 
operasi hitung dasar. Selain itu, aplikasi ini dapat meningkatkan minat siswa dalam belajar dan dapat dijadikan variasi untuk metode pembelajaran yang lebih interaktif baik didalam atau diluar kelas. Aplikasi edugame ini juga dapat berjalan dengan baik, dan seluruh fungsi yang ada didalam aplikasi sesuai dengan apa yang diharapkan oleh pengguna sesuai dengan hasil dari pengujian blackbox pada tabel 2 .

\section{DAFTAR PUSTAKA}

[1] Susanto, A. 2013. Teori belajar dan pembelajaran di sekolah dasar.

[2] Abdurrahman, M. 2012. Anak berkesulitan belajar. Jakarta: Rineka Cipta.

[3] Sutopo, H., \& Pamungkas, W. 2017. Developing mathematics mobile game to enhance learning for children. In 2017 IEEE International Conference on Computational Science and Engineering (CSE) and IEEE International Conference on Embedded and Ubiquitous Computing (EUC) (Vol. 1, pp. 191-197). IEEE.

[4] Hidayat, I. K., Sunarto, P., \& Guntur, T. 2014. Mengenal Relief, Mudra dan Stupa Candi Borobudur untuk Anak-Anak Usia 9-12 Tahun melalui Edugame. Journal of Visual Art and Design, 6(1), 58-68.

[5] Alvarez, J., \& Djaouti, D. 2011. An introduction to Serious game Definitions and concepts. Serious Games \& Simulation for Risks Management, 11, 1115.

[6] Vaughan, T.2011. Multimedia: Making it work. McGraw-Hill.

[7] Irsa, D., Saputra, R. W., \& Primaini, S. 2016. Perancangan Aplikasi Game Edukasi Pembelajaran Anak Usia Dini Menggunakan Linear Congruent Method (LCM) Berbasis Android. Jurnal Informatika Global, 6(1).

[8] Aini, B. O., Ayu, K. C., \& Siswati, S. 2019. Pengembangan Game Puzzle Sebagai Edugame Berbasis Android Untuk Meningkatkan Kemampuan Berpikir Matematika Siswa SD. JTAM $\mid$ Jurnal Teori dan Aplikasi Matematika, 3(1), 74-79.

[9] Adiwijaya, M., \& Christyono, Y. 2015. Perancangan game edukasi platform belajar matematika Berbasis android menggunakan construct 2. TRANSIENT, 4(1), 128-133.

[10] Balaji, S., \& Murugaiyan, M. S. 2012. Waterfall vs. V-Model vs. Agile: A comparative study on
SDLC. International Journal of Information Technology and Business Management, 2(1), 26-30.

[11] Shen, W., \& Liu, S. 2003. Formalization, testing and execution of a use case diagram. In International Conference on Formal Engineering Methods (pp. 68-85). Springer, Berlin, Heidelberg.

[12] Nidhra, S., \& Dondeti, J. 2012. Black box and white box testing techniques-a literature review. International Journal of Embedded Systems and Applications (IJESA), 2(2), 29-50

[13] Leung, H. K., \& Wong, P. W. 1997. A study of user acceptance tests. Software quality journal, 6(2), 137-149

[14] Likert RA. 1932. Technique for the measurement of attitudes. Archives of Psychology, 140 pp: 1-55

[15] Sugiyono, D. 2010. Metode penelitian kuantitatif dan R\&D. Bandung: Alfabeta. 